\title{
Transfer of the Nitrogen-Fixing Hydrogen Bacterium Corynebacterium autotrophicum Baumgarten et al. to Xanthobacter gen. nov.
}

\author{
JÜRGEN WIEGEL, ${ }^{1}$ DETLEF WILKE, ${ }^{2}$ JÖRG BAUMGARTEN, ${ }^{2}$ RAINER OPITZ, ${ }^{1}$ \\ AND HANS G. SCHLEGEL ${ }^{1}$ \\ Institut für Mikrobiologie der Gesellschaft für Strahlen und Umweltforschung mbH, Munich, ${ }^{1}$ and Institut \\ für Mikrobiologie der Universität Göttingen, 3400 Gottingen, ${ }^{2}$ Federal Republic of Germany
}

Thirty-five nitrogen-fixing, hydrogen-oxidizing bacteria, all members of Cory. nebacterium autotrophicum Baumgarten, Reh, and Schlegel 1974, and including the type strain of this species, were compared with 28 strains of coryneform bacteria by numerical taxonomy methods. The nitrogen-fixing hydrogen bacteria formed a well defined cluster; their similarity to the other strains tested was low, however. Furthermore, the chemotaxonomic characters of these strains excluded them from the coryneform bacteria. Therefore C. autotrophicum was reclassified, following the keys of Bergey's Manual of Determinative Bacteriology (8th ed.) as a species of the family Azotobacteraceae. Although taxonomically close to Beijerinckia and Derxia, the nitrogen-fixing, hydrogen-oxidizing bacteria are regarded as representing a new genus, for which we propose the name Xanthobacter. C. autotrophicum Baumgarten, Reh, and Schlegel is transferred to the new genus as Xanthobacter autotrophicus (Baumgarten et al.) comb. nov.

From 1969 to 1974, several coryneform, yellow-pigmented, autotrophic, hydrogen-oxidizing bacteria were described $(9,10,24,28)$; they were placed in a new species-Corynebacterium autotrophicum-by Baumgarten et al. (3). All of these strains fixed nitrogen under microaerobic conditions $(12,30)$, and the physiology and efficiency of their nitrogen fixation have been studied (4).

After isolating many new strains of nitrogenfixing hydrogen bacteria (30), we compared them with a number of well described coryneform bacteria by the method of numerical taxonomy. Since the nitrogen-fixing hydrogen bacteria formed a uniform cluster but had a very low similarity to the corynebacteria sensu stricto used in this investigation, a reclassification of $C$. autotrophicum appeared to be indicated. Additional biochemical properties of these organisms had to be determined before the organisms could be assigned to a gram-positive or a gram-negative taxon with confidence, for the evaluation of the Gram stain reaction, which differed from investigator to investigator, was the critical point in earlier descriptions of these organisms.

\section{MATERIALS AND METHODS}

Bacterial strains. The designations and sources of the bacterial strains used in this study are listed in Table 1. C. autotrophicum $7 \mathrm{C} \mathrm{SF}$ is a slime-free mutant of strain 7C (1).

Growth media. The strains were maintained on nutrient broth medium (Difco) containing $0.2 \%$ succinate and 1.3\% agar (Difco). For the taxonomic tests the strains were grown on the following mineral medium: $1.95 \mathrm{~g}$ of $\mathrm{KH}_{2} \mathrm{PO}_{4}, 5.7 \mathrm{~g}$ of $\mathrm{K}_{2} \mathrm{HPO}_{4}, 3.0 \mathrm{~g}$ of $\left(\mathrm{NH}_{4}\right)_{2} \mathrm{SO}_{4}, 0.2 \mathrm{~g}$ of $\mathrm{MgSO}_{4} \cdot 7 \mathrm{H}_{2} \mathrm{O}, 0.04 \mathrm{~g}$ of $\mathrm{CaCl}_{2} \cdot 2$ $\mathrm{H}_{2} \mathrm{O}, 0.003 \mathrm{~g}$ of $\mathrm{FeCl}_{3}, 13 \mathrm{~g}$ of agar (Difco), 2 to $5 \mathrm{~g}$ of the carbon source, $1 \mathrm{ml}$ of trace element solution (20), $10 \mathrm{ml}$ of vitamin solution (21), and distilled water to $1,000 \mathrm{ml}$. For autotrophic growth the mineral medium of Schlegel et al. (22) was used; the cultures were incubated under an atmosphere of $10 \% \mathrm{O}_{2}, 10 \% \mathrm{CO}_{2}$, and $80 \% \mathrm{H}_{2}$. For growth on nitrogen-free medium, the $\mathrm{N}$ source in the mineral medium was omitted; the cultures were incubated under an atmosphere of 5\% $\mathrm{O}_{2}, 10 \% \mathrm{CO}_{2}, 10 \% \mathrm{H}_{2}$, and $75 \% \mathrm{~N}_{2}$ (nitrogen fixation under autotrophic growth conditions) or of $25 \%$ air and $75 \% \mathrm{~N}_{2}$ in the presence of $0.5 \%$ sucrose or an appropriate carbon source (nitrogen fixation under heterotrophic growth conditions).

Staining methods. For the Gram stain, the modified method of Bartholomew (2) was used. Tetrazolium in vivo staining was performed by the method of Diena et al. (8). Volutin granules were stained for according to Albert and Laybourn's method as described in the Manual of Microbiological Methods (27).

Polyphosphate determination. Cells were grown on the mineral medium of Schlegel et al. (22) in which phosphate was gradually substituted by $\mathrm{NaHCO}_{3}$. No growth occurred in the original or modified medium of Neidhardt et al. (18). The polyphosphate content was then determined by the quantitative method of Kaltwasser and Schlegel (16).

Determination of poly- $\beta$-hydroxybutyric acid. Poly- $\beta$-hydroxybutyric acid was determined by the method described by Jüttner et al. (15).

Biochemical assays for numerical taxonomy. The characters used in the numerical taxonomy analysis are listed in Table 2. For determination of the 
utilization of sole carbon sources, solid and liquid versions of the mineral medium described above were used. Sugars as carbon source were added in a concentration of $5 \mathrm{~g} /$ liter; alcohols, organic acids, and amino acids were added in a concentration of $2 \mathrm{~g} /$ liter. Tests for autotrophic growth with hydrogen as energy source and for growth in nitrogen-free medium were performed as described above. The other diagnostic characters used were determined by the methods given in the Manual of Microbiological Methods (27) and in
Laboratory Methods in Microbiology (13). The tyrosinase test was performed by the procedure of Yamada and Komagata (32). Deoxyribonuclease and urease productions were determined with the corresponding Difco media.

Computer analysis. For the calculation of similarities among the strains, the similarity coefficient $S_{I}$ of Jaccard (25) was used. Clusters were then formed by single-linkage cluster analysis (26). The similarity data were then plotted as a dendrogram. The analysis

TABLE 1. Bacterial strains used in this study ${ }^{a}$

\begin{tabular}{|c|c|c|}
\hline Species & Strain & Source \\
\hline Arthrobacter atrocyaneus & AJ1429 & K. Komagata (Tokyo) \\
\hline A. simplex & ATCC 6946 & \\
\hline A. variabilis & AJ 1434 & K. Komagata \\
\hline A. tumescens & ATCC 6947 & K. Komagata \\
\hline Arthrobacter sp. & 9 & G. Auling (Gottingen) \\
\hline Arthrobacter sp. & RH 12 & M. Reh (Gottingen) \\
\hline Arthrobacter sp. & $11 \mathrm{X}$ & U. Eberhardt (Gottingen) \\
\hline Brevibacterium ammoniagenes & ATCC 6871 & K. Komagata \\
\hline B. ammoniagenes & ATCC 6872 & K. Komagata \\
\hline B. divaricatum & AJ 1498 & K. Komagata \\
\hline B. linens & AJ 1473 & K. Komagata \\
\hline B. lipolyticum & AJ 1450 & K. Komagata \\
\hline B. maris & AJ 1480 & K. Komagata \\
\hline B. stationis & ATCC 14403 & K. Komagata \\
\hline B. vitarumen & ATCC 10234 & K. Komagata \\
\hline Corynebacterium autotrophicum & 7C (DSM 432) (type strain) & DSM \\
\hline C. autotrophicum & 14g (DSM 431) & DSM \\
\hline C. autotrophicum & $\mathrm{RH} 9, \mathrm{RH} 10$ & M. Reh \\
\hline C. autotrophicum & $\begin{array}{l}\text { GZ 27, GZ 28, GZ 29, GZ30, GZ } \\
37, \text { GZ } 38\end{array}$ & G. Auling \\
\hline C. autotrophicum & $12 / 60 / x, 19 /-/ x$ & U. Ebertardt \\
\hline C. autotrophicum & OM 1 & O. Meyer (Gottingen) \\
\hline C. autotrophicum & $\begin{array}{l}\text { JW 1, JW 3, JW 4, JW 5, JW 6, } \\
\text { JW 7, JW 21, JW 22, JW 31, } \\
\text { JW 32, JW 33, JW 34, JW 35, } \\
\text { JW41, JW 42, JW 43, JW 44, } \\
\text { JW 46, JW 47, JW 48, JW 49, } \\
\text { JW 50 }\end{array}$ & J. Wiegel (Gottingen) \\
\hline C. equi & ATCC 6939 & K. Komagata \\
\hline C. barkeri & DSM 20145 & DSM \\
\hline C. betae & DSM 20141 & DSM \\
\hline C. fascians & DSM 20131 & DSM \\
\hline C. flaccumfaciens & DSM 20129 & DSM \\
\hline $\begin{array}{l}\text { C. flaccumfaciens subsp. auran- } \\
\text { tiacum }\end{array}$ & DSM 20135 & $\mathrm{DSM}$ \\
\hline C. herculis & ATCC 13868 & K. Komagata \\
\hline C. hoagic & ATCC 7005 & K. Komagata \\
\hline C. ilicis & DSM 20138 & DSM \\
\hline C. lilium & DSM 20137 & DSM \\
\hline C. manihot & DSM 20158 & DSM \\
\hline C. mediolanum & DSM 20152 & DSM \\
\hline C. poinsettiae & DSM 20149 & DSM \\
\hline C. rathayi & DSM 20153 & DSM \\
\hline C. $x$ erosis & DSM 20170 & DSM \\
\hline Microbacterium flavum & ATCC 13040 & K. Komagata \\
\hline Mycobacterium flavum & $(301=$ DSM 338$)$ & J. Postgate (Brighton) \\
\hline Micrococcus glutamicus & ATCC 13032 & K. Komagata \\
\hline
\end{tabular}

${ }^{a}$ Abbreviations: AJ, Central Research Laboratories, Ajinomoti Co., Japan; ATCC, American Type Culture Collection, Rockville, Md.; DSM, German Collection of Microorganisms, Germany. GZ, JW, OM, and RH are laboratory strain designations. 
was performed with a UNIVAC 1108 computer of the Gesellschaft für Wissenschaftliche Datenverarbeitung, Gottingen, Federal Republic of Germany.

Identification of the carotenoid pigment. The carotenoid pigment (crude carotenoids and acetylated derivatives) of C. autotrophicum $14 \mathrm{~g}$ and $7 \mathrm{C}$ and of Mycobacterium flavum 301 were compared by thinlayer chromatography and absorption spectroscopy as described by Nybraaten and Liaaen-Jensen (19).

\section{RESULTS AND DISCUSSION}

Numerical taxonomy. Thirty-five yellow coryneform nitrogen-fixing, autotrophic, hydrogen-oxidizing bacteria, all identified as strains of C. autotrophicum Baumgarten et al. (3), were compared by the methods of numerical taxonomy with 28 yellow or cream-colored strains of the genera Arthrobacter, Brevibacterium, Corynebacterium, and Microbacterium. The taxonomy of the reference strains was studied previously by Yamada and Komagata (32) and Schleifer and Kandler (23). Three arthrobacterlike autotrophic but not nitrogen-fixing strains were also included in the present study. One hundred-twenty (sometimes correlated) characters were used for the numerical taxonomy analysis; they were mainly those used by Yamada and Komagata (32) for grouping coryneform bacteria (Table 2).

The results of the single-linkage cluster analysis are given in Fig. 1.

The C. autotrophicum strains formed a distinct cluster above the level of $78 \%$ similarity; this cluster did not join any of the clusters formed by the other coryneform bacteria tested. Except for three strains (those of Microbacterium flavum, C. rathayi, and C. manihot), the reference strains linked before they joined the C. autotrophicum cluster. Linkage between the C. autotrophicum cluster and the other coryneform strains occurred at a similarity level of only $68 \%$. The three autotrophic arthrobacter-like strains formed a distinct cluster but did not show any relationship to $C$. autotrophicum. Although this analysis did not contain any reference strain outside the coryneform bacteria, it was obvious that $C$. autotrophicum does not belong to Corynebacterium or to a genus related to Corynebacterium.

Determination of a hypothetical median organism. Table 2 shows the number of $C$. autotrophicum strains positive for the characters used in the numerical taxonomy analysis. The properties of a hypothetical median organism were determined by assuming a character to be positive for the organism if more than 17 of the 35 tested strains were positive. Three strains (JW 32, JW 33, and JW 42) had characters identical to those of the hypothetical me- dian organism and therefore were most representative of $C$. autotrophicum. Four strains (JW 3 , JW 7, JW 41, and JW 48) differed from the hypothetical median organism in only one character. These seven strains, together with four others with two characters different from those of the hypothetical median organism and one strain with three mismatches, formed a welldefined subcluster in the $C$. autotrophicum taxon (Fig. 1).

Strain 7C, selected as the type strain of $C$. autotrophicum by Baumgarten et al. (3), differed in eight characters from the hypothetical median organism and therefore is relatively atypical of the species. For further taxonomic studies, therefore, we recommend the use of strain JW 33 as a reference for the taxon in addition to the type strain, $7 \mathrm{C}$.

Chemotaxonomic differences of $C$. autotrophicum from Corynebacterium. Besides the low overall similarity between $C$. autotrophicum and the coryneform reference strains, certain salient characters of C. autotrophicum precluded its membership in the genus Corynebacterium. None of the C. autotrophicum strains tested contained mycolic acids, which are typical of the coryneform bacteria (M. Goodfellow, personal communication; R. M. Kroppenstedt, personal communication). In all of the strains tested, meso-diaminopimelic acid was detected as diamino acid of the cell wall (O. Kandler and F. Fiedler, personal communication). The peptidoglycan was directly cross-linked by $m$-diaminopimelic acid (subgroup A1 [23]), as is typical of Corynebacterium sensu stricto, which is gram-positive, as well as of most gram-negative bacteria. However, besides peptidoglycan, Corynebacteriaceae contain arabinose and galactose as cell wall sugars; these were absent in the strains of C. autotrophicum tested (R. M. Kroppenstedt, personal communication). The fatty acid biosynthesis pathway of the nitrogen-fixing hydrogen bacteria so far examined is via cis. vaccenic acid, whereas that of the actinomycetes and the coryneform bacteria is via oleic acid ( $R$. $M$. Kroppenstedt, personal communication).

Gram stain reaction and related characters. On the basis of the observed differences between $C$. autotrophicum and the genus Cory. nebacterium, we attempted to reclassify $C$. autotrophicum with the aid of the keys in Bergey's Manual of Determinative Bacteriology (6). One of the first characters used in the generic key was the Gram reaction of the cell wall. In the earlier descriptions of the nitrogen-fixing hydrogen bacteria, the statements on the Gram reaction were contradictory. Using Bartholomew's (2) modification of the Gram stain and a number of strains cultivated under various growth con- 
TABLE 2. Properties of 35 Corynebacterium autotrophicum isolates determined for numerical taxonomy analysis ${ }^{a}$

\begin{tabular}{|c|c|c|c|}
\hline Property & $\begin{array}{l}\text { No. of strains giv- } \\
\text { ing a positive re- } \\
\text { action }\end{array}$ & Property & $\begin{array}{l}\text { No. of strains giv- } \\
\text { ing a positive re- } \\
\text { action }\end{array}$ \\
\hline Growth on: & & Gelatin liquefaction & $0(-)$ \\
\hline Acetate & $30(+)^{a}$ & Starch hydrolysis & $0(-)$ \\
\hline Citrate & $33(+)$ & Casein hydrolysis & $0(-)$ \\
\hline Lactate & $34(+)$ & Cellulose degration & $0(-)$ \\
\hline Formate & $6(-)$ & Tween hydrolysis & $0(-)$ \\
\hline Oxalate & $0(-)$ & Growth on tellurite agar & $15(-)$ \\
\hline \multirow[t]{2}{*}{ Succinate } & $35(+)$ & Growth with: & \\
\hline & & $2.5 \% \mathrm{NaCl}$ & $6(-)$ \\
\hline Malate & $35(+)$ & $5.0 \% \mathrm{NaCl}$ & $2(-)$ \\
\hline Fumarate & $34(+)$ & $7.5 \% \mathrm{NaCl}$ & $0(-)$ \\
\hline Malonate & $0(-)$ & $10.0 \% \mathrm{NaCl}$ & $0(-)$ \\
\hline \multirow{2}{*}{ Tartrate } & $0(-)$ & Growth at: & \\
\hline & & $25^{\circ} \mathrm{C}$ & $35(+)$ \\
\hline Pyruvate & $23(+)$ & $30^{\circ} \mathrm{C}$ & $35(+)$ \\
\hline Mandelate & $1(-)$ & $37^{\circ} \mathrm{C}$ & $34(+)$ \\
\hline Benzoate & $1(-)$ & $45^{\circ} \mathrm{C}$ & $3(-)$ \\
\hline Gluconate & $33(+)$ & $52^{\circ} \mathrm{C}$ & $0(-)$ \\
\hline Glyoxylate & $3(-)$ & Colonial properties & \\
\hline Glutarate & $29+)$ & Circular & $35(+)$ \\
\hline 2-Oxoglutarate & $31(+)$ & Irregular & $0(-)$ \\
\hline$\beta$-Hydroxybutyrate & $0(-)$ & Entire & $35(+)$ \\
\hline Glutamate & $35(+)$ & Undulate & $0(-)$ \\
\hline Alanine & $2(-)$ & Flat & $0(-)$ \\
\hline Threonine & $0(-)$ & Convex & $35(+)$ \\
\hline Valine & $0(-)$ & Umbonate & $0(-)$ \\
\hline Leucine & $1(-)$ & Raised & $2(-)$ \\
\hline Methionine & $0(-)$ & Translucent & $0(-)$ \\
\hline Lysine & $1(-)$ & Opaque & $35(+)$ \\
\hline Serine & $0(-)$ & Cream & $0(-)$ \\
\hline Arginine & $1(-)$ & Yellow & $35(+)$ \\
\hline Ornithine & $0(-)$ & Orange & $0(-)$ \\
\hline$\alpha$-Aminobutyrate & $0(-)$ & Pink & $0(-)$ \\
\hline Histidine & $0(-)$ & Rough & $0(-)$ \\
\hline Proline & $1(-)$ & Smooth & $35(+)$ \\
\hline Cysteine & $0(-)$ & Filiform & $35(+)$ \\
\hline Phenylalanine & $0(-)$ & Echinulate & $0(-)$ \\
\hline Arabinose & $0(-)$ & Growth in liquid medium (test tubes): & \\
\hline Xylose & $0(-)$ & Pellet & $35(+)$ \\
\hline Ribose & $0(-)$ & Flocky & $0(-)$ \\
\hline Rhamnose & $0(-)$ & Pellicular & $0(-)$ \\
\hline Glucose & $0(-)$ & Ring & $1(-)$ \\
\hline Fructose & $28(+)$ & Gram reaction & \\
\hline Mannose & $2(-)$ & Positive & $0(-)$ \\
\hline Galactose & $0(-)$ & Weakly positive & $35(+)$ \\
\hline Trehalose & $1(-)$ & Negative & $0(-)$ \\
\hline Sorbose & $0(-)$ & Metachromatic granules & $35(+)$ \\
\hline Sucrose & $24(+)$ & Cell wall is acid fast & $0(-)$ \\
\hline Lactose & $1(-)$ & Cell wall amino acid ${ }^{b}$ & \\
\hline Maltose & $0(-)$ & Ornithine & $-(-)$ \\
\hline Cellobiose & $0(-)$ & DL-Diaminopimelic acid & $+(+)$ \\
\hline Glycerol & $11(-)$ & LL-Diaminopimelic acid & $-(-)$ \\
\hline Mannitol & $1(-)$ & Nitrate reduction & $34(+)$ \\
\hline Sorbital & $1(-)$ & Voges-Proskauer reaction & $0(-)$ \\
\hline Inositol & $0(-)$ & Methyl red reaction & $0(-)$ \\
\hline Salicin & $0(-)$ & Indole production & $0(-)$ \\
\hline Propanol & $33(+)$ & $\mathrm{H}_{2} \mathrm{~S}$ production (7 days) & $0(-)$ \\
\hline Methanol & $34(+)$ & $\mathrm{H}_{2} \mathrm{~S}$ production (14 days) & $0(-)$ \\
\hline Ethanol & $34(+)$ & Lecithine hydrolysis & $0(-)$ \\
\hline
\end{tabular}


TABLE 2.-Continued.

\begin{tabular}{|c|c|c|c|}
\hline Property & $\begin{array}{l}\text { No. of strains giv- } \\
\text { ing a positive re- } \\
\text { action }\end{array}$ & Property & $\begin{array}{l}\text { No. of strains giv- } \\
\text { ing a positive re- } \\
\text { action }\end{array}$ \\
\hline $\begin{array}{l}\text { Autotrophic growth with } \mathrm{H}_{2} \text {, } \\
\mathrm{O}_{2} \text {, and } \mathrm{CO}_{2}\end{array}$ & $35(+)$ & Tetrazolium chloride reduction & $33(+)$ \\
\hline \multirow[t]{12}{*}{ Nitrogen fixation } & $35(+)$ & Litmus milk: & \\
\hline & & Alkaline & $33(+)$ \\
\hline & & Acid & $0(-)$ \\
\hline & & Clotting & $0(-)$ \\
\hline & & Clearing & $0(-)$ \\
\hline & & Production of: & \\
\hline & & Catalase & $35(+)$ \\
\hline & & Oxidase & $35(+)$ \\
\hline & & Urease & $1(-)$ \\
\hline & & Tyrosinase & $0(-)$ \\
\hline & & Phosphatase & $31(+)$ \\
\hline & & Deoxyribonuclease & $0(-)$ \\
\hline
\end{tabular}

${ }^{a}$ Character of the hypothetical median organism is given in parentheses: + , more than 17 strains positive for the treated property; -, less than 18 strains positive for the tested property.

${ }^{b}$ Only 12 strains were tested, all containing DL-diaminopimelic acid: 14g, 7C, GZ 29, GZ 29, GZ 38, 12/60/X, 9/-/x, OM 1, JW 21, JW34, JW43, and JW 44.

ditions, we found a positive reaction only in those regions of the cells containing refractile bodies; these bodies were visible by phase-contrast microscopy (30). Identical results were obtained using the tetrazolium staining method of Diena et al. (8). The refractile bodies, which apparently simulate gram-positive cell wall regions, were identified as polyphosphate granules by electron microscopy (29) as well as by volutin staining. Unfortunately, the polyphosphate content of the cells was high ( $15 \mathrm{mg}$ of phosphate per $g$ [dry weight]), and even at the minimum phosphate concentration in the growth medium $(0.01 \mathrm{mM})$, the volutin granules did not disappear. By electron microscopy of thin sections of cells (29), it was shown that the cell envelope of C. autotrophicum has a thin multilayered structure, clearly resembling that of gram-negative cells. The peptidoglycan content of the cell wall of the C. autotrophicum strains (15 to $25 \%$ ) was intermediate compared to that of gram-positive (30 to $70 \%$ ) and gram-negative $(10 \%)$ bacteria (23); teichoic acid and teichuronic acid, one or the other typically present in the cell walls of gram-positive bacteria, were absent $(0$. Kandler and F. Fiedler, personal communications). The cell envelopes of gram-negative bacteria contain lipopolysaccharides and lipoproteins. From strains 7C SF, 12/60/x, and JW 21, low but significant amounts of lipopolysaccharide could be isolated and analyzed (Wiegel and Mayer, manuscript in preparation). Furthermore, all strains tested contained ubiquinones $(\mathrm{Q} 10, \mathrm{Q} 10$ $\left[\mathrm{H}_{2}\right]$ ) but no menaquinones $(\mathrm{O}$. Thiele and $\mathrm{M}$. Goodfellow, personal communications). These properties indicate that $C$. autotrophicum is a gram-negative bacterium.

Cell morphology. Another salient characteristic in classifying bacteria-cell morphologystrongly favored inclusion of $C$. autotrophicum with the coryneform bacteria (3). The cell shape of $C$. autotrophicum was strongly influenced by growth conditions. Small rods $(0.5$ to 0.7 by 1.0 to $2.5 \mu \mathrm{m}$ ) were formed on autotrophic as well as sugar-containing media, whereas irregularly branched cells arranged in palisades were produced on a succinate medium (30; Fig. 2). On media containing alcohols such as $n$-butanol, small coccoid cells as well as rods up to $10 \mu \mathrm{m}$ long were formed. Distinct resting stages (arthrospores or cysts), even in $\beta$-hydroxybutyrateor butanol-containing media, were not found. The occurrence of a snapping type of cell division, as was assumed from light-microscope pictures of C. autotrophicum (3), was not confirmed by electron microscope studies. The illusion of snapping cell division may be due to copious amounts of slime or to outer cell wall layers holding the daughter cells together after cell division.

Reclassification of C. autotrophicum. According to the keys in Bergey's Manual of Determinative Bacteriology (6), the presently determined characters of $C$. autotrophicum lead one to the family Azotobacteraceae: gram-negative, aerobic to microaerophilic bacteria which do not produce endospores but which grow in nitrogen-free medium.

Table 3 shows the main diagnostic characters of the Azotobacteraceae and of C. autotrophi- 


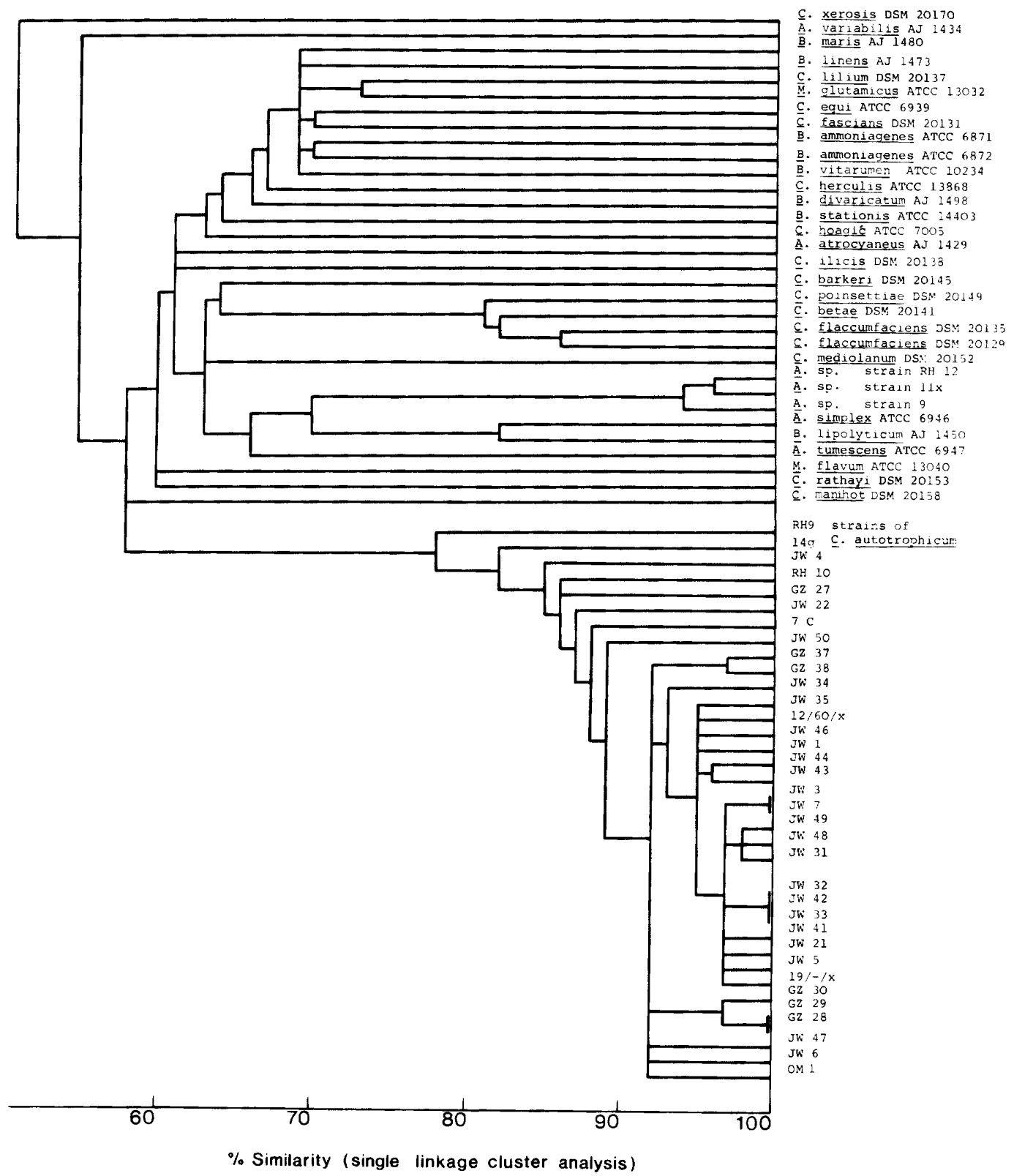

FIG. 1. Similarity dendrogram of strains used in the numerical taxonomic study.

cum. Within the Azotobacteraceae, C. autotrophicum is close to Beijerinckia and Derxia: small rods producing very tenacious extracellular slime or gum and conspicuous internal globular lipid bodies; slow growth; catalase may or may not be produced. The diagnostic difference between Beijerinckia and $C$. autotrophicum is the high guanine-plus-cytosine content $(70 \%)$ of the latter, and between $C$. autotrophicum and Derxia it is the production of catalase by the former. The characters of $C$. autotrophicum which clearly separate it from the four genera currently placed in the family Azotobacteraceae are its ability to grow autotrophically with hydrogen as energy source, its carbon utilization pattern, and its production of a water-insoluble, yellow, carotenoid pigment, zeaxanthin dirhamnoside $(14,19)$.

It is our opinion that $C$. autotrophicum belongs to a new genus of the family Azotobacter- 


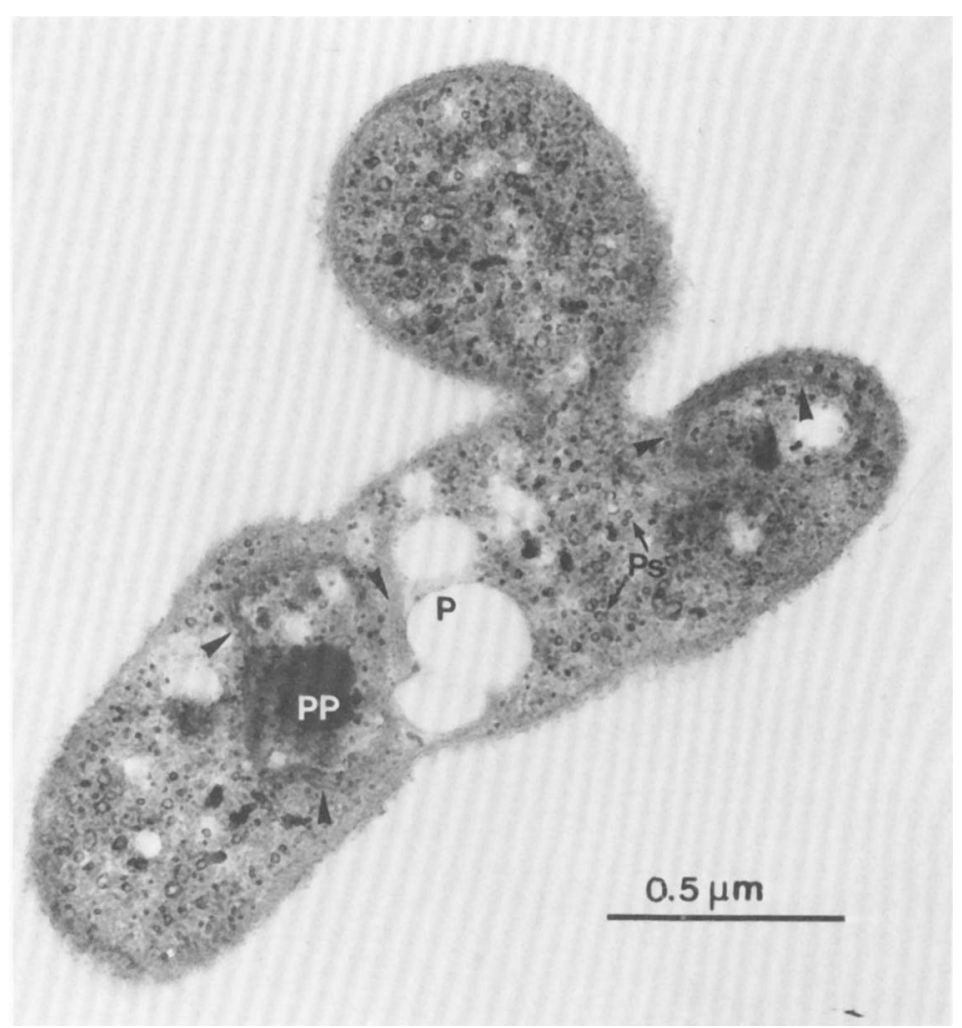

FIG. 2. Ultrathin section of C. autotrophicum $14 \mathrm{~g}$ grown on succinate-containing medium. Glutaraldehydeosmium tetroxide fixation, uranylacetate block staining, lead citrate post-staining; preparation by $A$. WaltherMauruschat. Abbreviations: $P$, poly- $\beta$-hydroxybutyrate; PP, polyphosphate; $P$ s, small-type polyphosphate.

TABLE 3. Diagnostic characters useful within the family Azotobacteracea ${ }^{a}$

\begin{tabular}{|c|c|c|c|c|c|}
\hline Character & $\begin{array}{l}\text { Corynebacterium } \\
\text { autotrophicum }\end{array}$ & Azotobacter & Azomonas & Beijerinckia & Derxia \\
\hline $\mathrm{G}+\mathrm{C}^{b}$ content & $69-70 \mathrm{~mol} \%$ & $63-66 \mathrm{~mol} \%$ & $53-59 \mathrm{~mol} \%$ & $55-59 \mathrm{~mol} \%$ & $70 \mathrm{~mol} \%$ \\
\hline Cyst formation & - & + & - & \pm & - \\
\hline Storage material & $\mathrm{PHB}^{c}$ & PHB & $?$ & PHB & PHB \\
\hline Refractile bodies & + & + & + & + & + \\
\hline Slime production & + & + & \pm & + & + \\
\hline Colony color & Yellow & Fluorescent & Fluorescent & Pink-brown & $\begin{array}{l}\text { Yellow- } \\
\text { brown }\end{array}$ \\
\hline \multicolumn{6}{|l|}{ Pigments } \\
\hline Water-soluble & - & + & + & + & + \\
\hline Water-insoluble & + & + & - & - & - \\
\hline Cell size (diam) & $0.4-1 \mu \mathrm{m}$ & $2 \mu \mathrm{m}$ & $2 \mu \mathrm{m}$ & $0.5-1.5 \mu \mathrm{m}$ & $1 \mu \mathrm{m}$ \\
\hline Pleomorphism & + & + & + & + & + \\
\hline Motility & - & \pm & + & \pm & + \\
\hline Catalase production & + & + & + & + & - \\
\hline pH range of growth & $5.8-9.0$ & $5.5-8.5$ & $4.5-9.0$ & $3.0-10.0$ & $5.5-9.0$ \\
\hline Gram reaction & Variable & $\begin{array}{l}\text { Negative to } \\
\text { variable }\end{array}$ & $\begin{array}{l}\text { Negative to } \\
\text { variable }\end{array}$ & Negative & Negative \\
\hline
\end{tabular}

\footnotetext{
${ }^{a}$ According to Bergey's Manual of Determinative Bacteriology (6).

${ }^{b} \mathrm{G}+\mathrm{C}$, Guanine plus cytosine

${ }^{c}$ PHB, Poly- $\beta$-hydroxybutyrate.
} 
aceae, for which we propose the name Xanthobacter (Xan.tho.bac'ter. Gr. adj. xanthos yellow; M.L. masc. $n$. bacter the equivalent of Gr. neut. n. bacterion rod, staff; M.L. masc. n. Xanthobacter yellow rod). The name of this organism thus becomes Xanthobacter autotrophicus (Baumgarten, Reh, and Schlegel 1974) comb. nov.

The description of Xanthobacter gen. nov. is as follows. Small, rod-shaped cells 0.4 to 1.0 by 0.8 to $6.0 \mu \mathrm{m}$; branched, rather pleomorphic cells are produced on succinate-containing medium, and coccoid as well as cells up to $10 \mu \mathrm{m}$ long are produced on media containing an alcohol as the sole carbon source. Refractile (polyphosphate) and lipid (poly- $\beta$-hydroxybutyrate) bodies are contained within the whole cell.

Nonmotile. Resting stages are unknown. Gram-negative type of cell wall, but the Gram reaction is variable; the cell wall contains peptidoglycan directly linked by $m$-diaminopimelic acid; lipopolysaccharides are present in the cell wall but teichoic and teichuronic acids are absent. Agar colonies are opaque and slimy; slimefree strains also exist. Colonies are yellow due to a water-insoluble carotenoid pigment, zeaxanthin dirhamnoside.

Grow as chemolithoautotrophs in mineral medium under an atmosphere of hydrogen, oxygen, and carbon dioxide (7:2:1 by volume) as well as chemoorganotrophically on methanol, ethanol, $n$-propanol, $n$-butanol, and many organic acids used as sole carbon sources; carbohydrate utilization is limited. Neither acid nor gas is produced from carbohydrates.

Atmospheric nitrogen is fixed in nitrogen-deficient media under reduced oxygen pressure with an efficiency of more than 10 and usually $20 \mathrm{mg}$ of $\mathrm{N}$ per $\mathrm{g}$ of sucrose consumed.

Obligately aerobic. Catalase positive.

Optimal growth temperature: 25 to $30^{\circ} \mathrm{C}$. pH range for optimal growth: 5.8 to 9.0 .

Guanine-plus-cytosine content of the deoxyribonucleic acid: 69 to $70 \mathrm{~mol} \%$.

Isolated from soil, mud, and water.

Type species: Xanthobacter autotrophicus (Baumgarten, Reh, and Schlegel 1974) comb. nov.

The new taxonomic position of C. autotrophicum, as determined by the keys in Bergey's Manual of Determinative Bacteriology (6), does not suggest a systematic or evolutionary relationship to the other genera of the family Azotobacteraceae. The ribosomal ribonucleic acid homology might be taken as a criterion of the natural relationships between strains. The ribosomal ribonucleic acid properties of our strains were studied by J. DeLey (personal communication). They are far from those of Azotobacter and Derxia and closest to, but still quite different from, those of Beijerinckia. The Azotobacteraceae themselves, however, are heterogeneous with respect to ribosomal ribonucleic acid homology. Therefore, the ribosomal ribonucleic acid property of $X$. autotrophicus is not considered as justification for excluding this species from this physiologically homogeneous family.

No taxonomic relationship of $X$. autotrophicus to members of Xanthomonas, Flavobacterium, Chromobacterium, Cytophaga, the Methylomonadaceae, or other taxa of questionable taxonomic position was found with respect to such characteristic properties as irregular cell shape, colony pigmentation, slime production, guanine-plus-cytosine content, Gram variability, nitrogen fixation, autotrophic growth, methanol utilization, and limited pattern of carbohydrate utilization.

Relationship of Mycobacterium flavum 301 to $X$. autotrophicus. This study was not concerned with the taxonomy of Mycobacterium flavum 301, which was isolated as a nitrogenfixing bacterium (11) and was later found to resemble the other nitrogen-fixing hydrogen bacteria (7; Zavarzin, personal communication). Nevertheless, there is no doubt that Mycobacterium flavum 301 does not belong to Mycobacterium flavum in Krasil'nikov's scheme (17) nor to Microbacterium flavum Orla-Jensen 1919 (5) but that it clearly resembles the members of $X$. autotrophicus: Mycobacterium flavum 301 does not contain arabinogalactan or any type of mycolic acid (R. M. Kroppenstedt, personal communication); it contains ubiquinone but no menaquinones $(O$. Thiele, personal communication); it has the same fatty acid pattern as $X$. autotrophicus (R. M. Kroppenstedt, personal communication); it has the same carotenoid pigment as X. autotrophicus $14 \mathrm{~g}$ and $7 \mathrm{C}$ as determined by chromatography and by the absorption spectrum; its carbon utilization pattern is comparable to those of $X$. autotrophicus $14 \mathrm{~g}$ and RH 9, which are also unable to utilize carbohydrates; it shows the same characteristic change in cell morphology caused by the addition of succinate to the medium; and the regulation of the leucine biosynthetic enzyme $\alpha$-isopropylmalate synthase activity is similar to that of Xanthobacter but not to that of Mycobacterium and Corynebacterium (31). Strain 301 gives similar results as $X$. autotrophicus with the various staining procedures for cells and volutin granules, and the electron micrographs of thin sections show similar cell wall structures.

\section{ACKNOWLEDGMENTS}

We thank several colleagues for providing data: F. Fiedler and $\mathrm{O}$. Kandler, Botanisches Institut der Universität, Munich; 
R. M. Kroppenstedt, DSM, Darmstadt; M. Goodfellow, University of Newcastle-upon-Tyne, Newcastle-upon-Tyne; $O$. W. Thiele, Physiologisch-chemisches Institut der Universität Göttingen, Göttingen; and J. DeLey, Laboratorium voor microbiologie en microbiele genetica, Rijksuniversiteit Gent. We also thank D. Claus, K. Schmidt, and M. Reh, at the Institut für Mikrobiologie der Universität Göttingen, for many helpful discussions.

This investigation was partially supported by a grant from Förderungsmittel des Landes Niedersachsen.

\section{REPRINT REQUESTS}

Address reprint requests to: Dr. Hans Günter Schlegel, Institut für Mikrobiologie der Universitat Göttingen, Grisebachstrasse 8, 3400 Göttingen, Federal Republic of Germany.

\section{LITERATURE CITED}

1. Andreesen, M., and H. G. Schlegel. 1974. A new coryneform hydrogen bacterium: Corynebacterium autotrophicum strain 7C. II. Isolation of a slime-free mutant. Arch. Microbiol. 100:351-361.

2. Bartholomew, J. W. 1962. Variables influencing results and the precise definition of steps in Gram staining as a means of standardizing the results obtained. Stain Technol. 37:139-155.

3. Baumgarten, J., M. Reh, and H. G. Schlegel. 1974. Taxonomic studies on some Gram-positive coryneform hydrogen bacteria. Arch. Microbiol. 100:207-217.

4. Berndt, H., K.-P. Ostwal, J. Lalucat, C. Schumann, F. Mayer, and H. G. Schlegel. 1976. Identification and physiological characterization of the nitrogen-fixing bacterium Corynebacterium autotrophicum GZ29. Arch. Microbiol. 108:17-26.

5. Biggins, D. R., and J. R. Postgate. 1971. Confusion in the taxonomy of a nitrogen-fixing bacterium currently classified as Mycobacterium flavum 301. J. Gen. Microbiol. 65:119-123.

6. Buchanan, R. E., and N. E. Gibbons. 1974. Bergey's manual of determinative bacteriology, 8th ed. The Williams \& Wilkins Co., Baltimore.

7. DeBont, J. A. M., and M. W. M. Leijten. 1976. Nitrogen fixation by hydrogen-utilizing bacteria. Arch. Microbiol. 107:235-240

8. Diena, B. B., R. Wallace, and L. Greenberg. 1962. Gram reaction and tetrazolium staining. Can. J. Microbiol. 8:99-103.

9. Eberhardt, U. 1969.On chemolithotrophy and hydrogenase of a Gram-positive Knallgas bacterium. Arch. Mikrobiol. 66:91-104.

10. Eberhardt, U. 1971. The cell wall as the site of carotenoid in the "Knallgas" bacterium, 12/60/x. Arch. Mikrobiol. 80:32-37.

11. Federov, M. N., and T. A. Kalininskaya. 1961. A new species of nitrogen-fixing Mycobacterium and its physiological properties. Mikrobiologiya 30:9-14.

12. Gogotov, J. N., and H. G. Schlegel. 1974. $\mathbf{N}_{2}$-fixation by chemoautotrophic hydrogen bacteria. Arch. Microbiol. 97:359-362.

13. Harrigan, W. F., and M. E. McCance. 1966. Laboratory methods in microbiology. Academic Press Inc., London.

14. Hertzberg, S., G. Brock, and S. Liaaen-Jensen. 1976 Bacterial carotenoids. L. Absolute configuration of zeaxanthin dirhamnoside. Arch. Microbiol. 110:95-99.
15. Jüttner, R.-R., R. M. Lafferty, and H. J. Knackmuss. 1975. A simple method for the determination of poly$\beta$-hydroxybutyric acid in microbial biomass. Eur. J. Appl. Microbiol. 1:233-237.

16. Kaltwasser, H., and H. G. Schlegel. 1959. Nachweis und quantitative Bestimmung der Polyphosphate in Wasserstoff oxydierenden Bakterien. Arch. Mikrobiol. 34:76-92.

17. Krasil'nikov, N. A. 1959. Diagnostik der Bakterien und Actinomyceten. VEB Gustav Fischer Verlag, Jena. (German translation of 1949 Russian edition).

18. Neidhardt, F. C., P. L. Bloch, and D. F. Smith. 1974. Culture medium for enterobacteria. J. Bacteriol. 119:736-747.

19. Nybraaten, G., and S. Liaaen-Jensen. 1974. Bacterial carotenoids. XLIV. Zeaxanthin mono- and dirhamnoside. Acta Chem. Scand. Ser. B 28:1219-1224.

20. Ormerod, J. G., K. S. Ormerod, and H. Gest. 1961 Light dependent utilization of organic compounds and photoproduction of molecular hydrogen by photosynthetic bacteria; relationships with nitrogen metabolism. Arch. Biochem. Biophys. 94:449-463.

21. Pfennig, N. 1965. Anreicherungskulturen für rote und grüne Schwefelbakterien. In H. G. Schlegel (ed.), Anreicherungskultur und Mutantenauslese. Zentralbl. Bakteriol. Parasitenkd. Infektionskr. Hyg. Abt. I Suppl. 1:179-189.

22. Schlegel, H. G., H. Kaltwasser, and G. Gottschalk. 1961. Ein Submersverfahren zur Kultur wasserstoffoxydierender Bakterien: Wachstumsphysiologische Untersuchungen. Arch. Mikrobiol. 38:209-222.

23. Schleifer, K. H., and O. Kandler. 1972. Peptidoglycan types of bacterial cell walls and their taxonomic implications. Bacteriol. Rev. 34:407-477.

24. Schneider, K., V. Rudolph, and H. G. Schlegel. 1973. Description and physiological characterization of a coryneform hydrogen bacterium strain 14g. Arch. Mikrobiol. 93:179-193.

25. Sneath, P. H. A. 1957. Some thoughts on bacterial classification. J. Gen. Microbiol. 17:184-200.

26. Sneath, P. H. A. 1957. The application of computers to taxonomy. J. Gen. Microbiol. 17:201-226.

27. Society of American Bacteriologists. 1957. Manual of microbiological methods. McGraw-Hill, New York.

28. Tunail, N., and H. G. Schlegel. 1974. A new coryneform hydrogen bacterium: Corynebacterium autotrophicum strain 7C. I. Characterization of the wild type strain. Arch. Microbiol. 100:341-350.

29. Walther-Mauruschat, A., M. Aragno, F. Mayer, and H. G. Schlegel. 1977. Micromorphology of Gram-negative hydrogen bacteria. II. Cell envelope, membranes, and cytoplasmic inclusions. Arch. Microbiol. 114:101-110.

30. Wiegel, J., and H. G. Schlegel. 1976. Enrichment and isolation of nitrogen-fixing hydrogen bacteria. Arch. Microbiol. 107:139-142.

31. Wiegel, J., and H. G. Schlegel. 1977. Leucine biosynthesis: effect of branched-chain amino acids and threonine on $\alpha$-isopropylmalate synthase activity from aerobic and anaerobic microorganisms. Biochem. Syst. Ecol. 5:169-176.

32. Yamada, K., and K. Komagata. 1972. Taxonomic studies on coryneform bacteria. IV. Morphological, cultural, biochemical, and physiological characteristics. J. Gen. Appl. Microbiol. 18:399-416. 